\title{
Penerapan Model Everyone Is a Teacher Here Dalam Meningkatkan Motivasi Siswa Kelas V Pada Pembelajaran PKn
}

\author{
Silvia Meirisa \\ STKIP Muhammadiyah Sungai Penuh, Jambi \\ meirisasilvia2@gmail.com
}

\begin{abstract}
The background of the problem in this study is due to the low motivation of students in Civics learning, it can be seen that the teacher always uses the lecture method and a few questions and answers, while the existence of students as creative people is less attention. The purpose of this study is to describe the increase in student motivation to ask questions and answer questions using the Everyone is a Teachere Here model. The type of research used in this research is Classroom Action Research (PTK). Thirteen students of grade V SDN 138 / III Tanjung Syam Kerinci are the subjects of this study. The results showed that the students' motivation in asking questions obtained a percentage in cycle I from $34.58 \%$ increased in cycle II to $76.92 \%$, student learning motivation in answering questions obtained a percentage in cycle I from $53.84 \%$ increased in cycle II. to $80.76 \%$, then the average value of learning outcomes in cycle I from 65.38 increased in cycle II to 78.07. The results of this study can be concluded that student learning motivation can be improved through the Everyone is a Teachere Here model in class V SD in Civics learning.
\end{abstract}

Keywords: learning motivation; PKn; everyone is a teachere here

\begin{abstract}
ABSTRAK
Latarbelakang permasalahan dalam penelitian ini dikarenakan rendahnya motivasi belajar siswa pada pembelajaran PKn, hal tersebut terlihat bahwa guru selalu menggunakan metode ceramah dan sedikit tanya jawab, sedangkan keberadaaan siswa sebagai seorang yang kreatif kurang diperhatikan. Tujuan dari penelitian ini yaitu untuk mendeskripsikan peningkatkan motivasi belajar siswa mengajukan pertanyaan dan menjawab pertanyaan dengan menggunakan model everyone is a teachere here. Adapun jenis penelitian yang dipakai dalam penelitian ini adalah Penelitian Tindakan Kelas (PTK). Siswa kelas V SDN 138/III Tanjung Syam Kerinci yang berjumlah 13 orang adalah subjek dari penelitian ini. Hasil penelitian menunjukkan bahwa motivasi belajar siswa dalam mengajukan pertanyaan diperoleh persentase pada siklus I dari 34,58\% meningkat pada siklus II menjadi 76,92\%, motivasi belajar siswa dalam menjawab pertanyaan diperoleh persentase pada siklus I dari 53,84\% meningkat pada siklus II menjadi 80,76\%, kemudian rata-rata nilai hasil belajar siklus I dari 65,38 meningkat pada siklus II menjadi 78,07. Hasil dari penelitian ini dapat disimpulkan bahwa motivasi belajar siswa dapat ditingkatkan melalui model everyone is a teachere here di kelas V SD pada pembelajaran PKn.
\end{abstract}

Kata Kunci: motivasi belajar; PKn; everyone is a teachere here

Submitted Apr 15, 2021 | Revised May 08, 2021 | Accepted May 11, 2021

\section{Pendahuluan}

Pendidikan merupakan bagian yang tidak dapat dipisahkan dalam pembangunan. Berbicara tentang proses pendidikan sudah pasti tidak dapat dipisahkan dengan semua upaya yang mesti dilakukan untuk meningkatkan sumber energi manusia yang bermutu, sedangkan manusia yang bermutu itu dilihat dari segi pembelajaran sudah tercantum secara jelas dalam tujuan pendidikan nasional. Menurut Hamalik (2011) menerangkan bahwa pendidikan ialah suatu proses mempengaruhi siswa agar dapat membiasakan diri sebaik mungkin dengan lingkungannya. Pada dasarnya pertumbuhan serta perkembangan siswa bergantung pada dua faktor yang saling mempengaruhi, yaitu bakat yang dimiliki oleh siswa sejak lahir, serta lingkungan yang mempengaruhi sampai bakat itu tumbuh dan berkembang (Farikhah, 2009; Samio, 2018; Musdalifah, 2019). Sekolah selaku lembaga pendidikan formal, secara sistematis merancang beragam lingkungan yaitu berupa lingkungan pendidikan yang menyediakan berbagai peluang buat siswa untuk melaksanakan berbagai aktivitas belajar. Dengan kesempatan belajar tersebut, petumbuhan serta perkembangan siswa diarahkan dan didorong untuk 
mencapai tujuan yang diinginkan. Lingkungan tersebut disusun serta ditata dalam suatu kurikulum, serta dilaksanakan dalam bentuk proses pembelajaran (Sudana, et al., 2017).

Pembelajaran Kewarganegaraan (PKn) ialah salah satu mata pelajaran yang diajarkan di sekolah, mulai dari jenjang pendidikan dasar hingga ke pendidikan menengah, ataupun di perguruan tinggi. Menurut Yusrizal (2010) visi dalam pembelajaran PKn ialah mewujudkan proses pembelajaran yang tidak dapat dipisahkan di sekolah buat meningkatkan keahlian serta karakter warga negara yang cerdas, turut dan juga serta bertanggung jawab yang pada gilirannya bakal sebagai suatu landasan berkembangnya warga Indonesia yang demokratis. PKn ialah wahana dalam meningkatkan dan melestarikan nilai luhur serta moral dan budaya bangsa Indonesia yang diharapkan bisa diwujudkan dalam bentuk perilaku kehidupan sehari- hari siswa selaku individu serta anggota masyarakat dalam kehidupan berbangsa dan bernegara (Supriadi \& Matnuh, 2014; Astuti, 2016; Rostini, 2018; Andriani, 2020).

Hasil observasi peneliti dengan guru kelas V di SDN 138 Tanjung Syam Kecamatan Bukit Kerman Kabupaten Kerinci Provinsi Jambi, menunjukan bahwa banyak siswa yang tidak termotivasi dalam pelajaran PKn. Hal tersebut terlihat bahwa guru selalu menggunakan metode ceramah dan sedikit tanya jawab, sedangkan keberadaaan siswa sebagai seorang yang kreatif kurang diperhatikan. Dimana pada saat guru mengajar terlihat bahwa siswa hanya terfokus pada guru, karena itu siswa cenderung pasif dan tenang. Siswa hanya mendengarkan dan menunggu apa yang disuruh oleh guru. Siswa juga kurang diberi kesempatan untuk berpatisipasi dalam pembelajaran, sehingga siswa merasa bosan dan tidak bersemangat dalam belajar. Ditinjau dari motivasi belajar siswa yang sangat rendah, terlihat dari kurangnya siswa yang mengajukan pertanyaan atau menjawab pertanyaan dari guru. Kemudian dari hasil wawancara peneliti dengan guru kelas V di SD Tanjung Syam Penuh Kecamatan Bukit Kerman Kabupaten Kerinci Provinsi Jambi, selama proses pembelajaran dengan menggunakan metode ceramah dan sedikit tanya jawab, guru menjelaskan materi pembelajaran terlebih dahulu dan di akhir pembelajaran siswa diberikan kesimpulan dan tugas. Secara tidak langsung mengakibatkan kurangnya motivasi dan keaktifan siswa dalam belajar, serta kurangnya interaksi antara siswa dan guru. Selain itu, peneliti juga memperoleh informasi bahwa rata-rata skor hasil belajar yang diperoleh oleh siswa dalam beberapa kali pelaksanaan ulangan harian belum optimal dan belum mencapai standar Kriteria Ketuntasan Minimal (KKM) yang ditetapkan oleh sekolah tersebut yakni $\geq 70$. Hal ini berarti masih ada beberapa orang siswa yang belum mencapai standar KKM.

Rendahnya hasil belajar yang diperoleh siswa pada mata pelajaran PKn disebabkan oleh pelaksanaan pembelajaran yang dilakukan oleh guru selama ini cenderung menggunakan metode ceramah dan sedikit tanya jawab. Dalam hal ini setiap pembelajaran yang dilakukan hanya di dominasi oleh guru. Kurangnya motivasi siswa dalam pembelajaran dapat terlihat dengan adanya beberapa orang siswa yang mengantuk, melamun, dan ada juga siswa yang suka melihat-lihat di luar kelas. Berdasarkan permasalahan tersebut, jelas terlihat bahwa siswa merasa jenuh dan bosan terhadap model pembelajaran yang diberikan oleh guru.

Hamalik (2011) Mc. Donald mengatakan bahwa motivasi merupakan perubahan energi yang terdapat dalam diri seseorang yang ditandai dengan timbulnya perasaan dan reaksi untuk mencapai tujuan. Oleh sebab itu, perbuatan seseorang yang didasarkan atas motivasi tertentu mengandung tema sesuai dengan motivasi yang mendasarinya. Pada kegiatan belajar, motivasi dapat dikatakan sebagai keseluruhan daya penggerak di dalam diri siswa yang menimbulkan kegiatan belajar dan yang memberikan arah pada kegiatan belajar, sehingga tujuan yang dikehendaki oleh subjek balajar itu dapat tercapai. Jadi, tugas guru bagaimana mendorong para siswa agar pada dirinya tumbuh motivasi. Motivasi merupakan proses untuk menggaitkan motif-motif menjadi perbuatan dalam mencapai tujuan atau keadaan serta kesiapan dalam diri seseoarang yang mendorong tingkah lakunya untuk berbuat sesuatu dalam mencapai tujuan yang diinginkan (Hamdi, 2011). Menurut Kompri (2016) motivasi belajar merupakan segi kejiwaan yang mengalami perkembangan. Itu artinya motivasi tersebut 
terpengaruh oleh kondisi fisiologis dan kematangan psikologis siswa. Adapun unsur-unsur yang mempengaruhi motivasi dalam belajar yaitu: (1) cita-cita dan aspirasi siswa. cita-cita akan memperkuat motivasi belajar siswa baik intrinsik maupun ekstrinsik, (2) kemampuan siswa. keinginan seorang anak perlu dibarengi dengan kemampuaan dan kecakapan dalam pencapaiannya, (3) kondisi siswa. kondisi siswa yang meliputi kondisi jasmani dan rohani. seorang siswa yang sedang sakit akan mengganggu perhatian dalam belajar, (4) kondisi lingkungan siswa. lingkungan siswa dapat berupa lingkungan alam, lingkungan tempat tinggal, pergaulan sebaya dan kehidupan bermasyarakat. Hakikat motivasi belajar menurut Simarmata (2013) adalah dorongan internal dan eksternal pada siswa-siswa yang sedang belajar untuk mengadakan perubahan tingkah laku. Hal itu mempunyai peranan besar dalam keberhasilan individu dalam belajar. Dalam kegiatan belajar, motivasi dapat dikatakan sebagai keseluruhan daya penggerak di dalam diri siswa yang menimbulkan kegiatan belajar, yang menjamin kelangsungan dari kegiatan belajar dan yang memberikan arah pada kegiatan belajar, sehingga tujuan yang dikehendaki oleh subjek belajar itu dapat tercapai. Siswa yang memiliki motivasi kuat, akan mempunyai banyak energi untuk melakukan kegiatan belajar.

Berdasarkan permasalahan-permasalahan yang telah dijelaskan di atas, peneliti bermaksud untuk memberikan solusi terhadap permasalahan tersebut. Salah satu model pembelajaran yang dapat digunakan untuk meningkatkan motivasi belajar siswa yaitu model pembelajaran everyone is a teacher here. Model pembelajaran everyone is a teacher here merupakan salah satu model pembelajaran yang dapat mengaktifkan siswa untuk berpatisipasi dalam proses pembelajaran. Menurut Taufik dan Muhammadi (2009) bahwa model pembelajaran everyone is a teacher here memiliki makna bahwa setiap orang adalah guru. Model pembelajaran tersebut memberi kesempatan kepada siswa untuk berperan sebagai guru bagi teman-temannya. Shoimatul (2013) menjelaskan bahwa model everyone is a teacher here memberi kesempatan kepada siswa untuk berperan menjai guru, sehingga dapat melatih siswa dalam mengungkapkan pertanyaan dan menjawab pertanyaan sesuai dengan anasisnya sendiri. Model everyone is a teacher here menurut Silberman (2016) yaitu model pembelajaran yang dapat membuat siswa lebih aktif, model tersebut meberi kesempatan kepada siswa menjadi guru bagi. Adapun langkah-langkah model pembelajaran everyone is a teacher here yaitu: (1) guru membagi secarik kertas atau kartu indeks kepada semua siswa, (2) setia siswa diminta untuk menuliskan satu pertanyaan mengenai materi pembelajaran yang sedang dilaksanakan, (3) siswa diminta mengumpulkan kertas yang berisi pertanyaan dan membagikan kembali ke siswa dengan catatan tidak ada siswa yang mendapat soal dirinya sendiri, (4) siswa kemudian memikirkan apa jawaban dari pertayaan yang diperolehnya dari kertas tersebut, (5) siswa diminta untuk membacakan pertanyaan yang didapatkan dari kertas tersebut, kemudian memberi jawabannya.

Berdasarkan latar belakang di atas, maka tujuan penelitian adalah untuk mendeskripsikan peningkatkan motivasi belajar siswa mengajukan pertanyaan dan menjawab pertanyaan dengan menggunakan model everyone is a teachere here.

\section{Metode Penelitian}

Penelitian ini menggunakan Penelitian Tindakan Kelas (PTK). Menurut Suharsimi, et.,al (2015) bahwa Penetian Tindakan Kelas adalah penelitian tindakan yang dilakukan oleh guru dengan tujuan memperbaiki mutu praktik pembelajaran di kelasnya, PTK terdiri dari empat komponen yaitu perencanaan, pelaksanaan, pengamatan, dan refleksi. Sanjaya (2014) mengatakan bahwa Penelitian Tindakan Kelas merupakan proses pengkajian masalah yang terdapat pada suatu pembelajaran di dalam kelas melalui refleksi diri, upaya dalam pemecahan masalah dengan cara melakukan berbagai tindakan yang terencana dalam situasi nyata dengan cara menganalisis pengaruh dari pelakuan tersebut.

Penelitian ini dilaksanakan di SDN 138 Tanjung Syam Kecamatan Bukit Kerman Kabupaten Kerinci Provinsi Jambi. Subjek dari penelitian ini adalah siswa kelas V SDN 138/III Tanjung Syam Kerinci yang berjumlah 13 orang, terdiri dari laki-laki sebanyak 5 orang dan perempuan sebanyak 8 
orang. Penelitian ini berlangsung di semester II melalui 2 siklus. Sumber data dalam penelitian ini yaitu kegiatan belajar PKn yang meliputi perencanaan, pelaksanaan pembelajaran, evaluasi pembelajaran, perilaku guru dan siswa sewaktu proses pembelajaran berlangsung. Instrumen pengumpulan data dalam penelitian ini adalah lembar observasi kegiatan guru, lembar observasi motivasi belajar siswa, angket motivasi siswa, dan tes hasil belajar. Teknik Analisis data dalam penelitian ini yaitu data observasi kegiatan guru, data observasi motivasi belajar siswa, data analisis angket belajar siswa, dan data hasil belajar. Data yang diperoleh dianalisis secara kualitatif. Data-data yang dihasilkan secara kualitatif diolah dengan metode kuantitatif. Analisis data secara kuantitatif dapat berbentuk angka, huruf ataupun persen.

\section{Hasil dan Pembahasan}

\section{Hasil Belajar PKn Siswa}

PTK dalam penelitian ini terdiri dari dua siklus, yang setiap siklusnya terdiri dari dua kali pertemuan dan satu kali tes akhir siklus. Proses pembelajaran dilaksanakan dengan penerapan model everyone is a teacher here untuk meningkatkan motivasi belajar siswa. Berdasarkan hasil tes siklus I dan siklus II, persentase siswa yang tuntas mengikuti tes dan rata-rata skor tesnya dapat dilihat pada tabel berikut:

Tabel 1. Hasil Belajar PKn Siswa pada Siklus I dan Siklus II

\begin{tabular}{lcc}
\hline \multirow{2}{*}{ Uraian } & \multicolumn{2}{c}{ Siklus } \\
\cline { 2 - 3 } & I & II \\
\hline Jumlah siswa yang mengikuti tes & 13 & 13 \\
Jumlah siswa yang tuntas tes & 4 & 10 \\
Jumlah siswa yang tidak tuntas tes & 9 & 4 \\
Persentase ketuntasan tes & $30,76 \%$ & $76,92 \%$ \\
\hline Rata-rata nilai tes & 65,38 & 78,07 \\
\hline
\end{tabular}

Berdasarkan Tabel 1 di atas, terlihat bahwa persentase ketuntasan hasil belajar siswa pada siklus I yaitu 65,38\% masih tergolong rendah dan rata-rata nilai tes secara keseluruhan belum mencapai KKM yang ditetapkan yaitu 70\%. Target ketuntasan belajar yang ditetapkan oleh peneliti pada indikator keberhasilan ketuntasan belajar secara klasikal yaitu $70 \%$ dari jumlah siswa, sedangkan ketercapaian ketuntasan belajar pada siklus I ini belum mencapai target ketuntasan belajar. Pada siklus II persentasi hasil belajar siswa yaitu 78,07\%, berarti hasil belajar siswa meningkat dan sudah mencapai KKM.

2. Hasil Observasi Proses Kegiatan Guru dalam Pelaksanaan Pembelajaran

Lembar observasi proses kegiatan guru dalam pelaksanaan pembelajaran pada siklus I dan siklus II dapat dilihat pada tabel berikut ini.

Tabel 2. Persentase Kegiatan Guru dalam Proses Pelaksanaan Pembelajaran Siklus I dan Siklus II

\begin{tabular}{ccc}
\hline Siklus & Persentase & Keterangan \\
\hline I & $62,49 \%$ & Cukup Baik \\
II & $83,33 \%$ & Baik \\
\hline
\end{tabular}

Dapat dilihat analisis pada tabel di atas, pada siklus I persentase guru dalam kegiatan pembelajaran memiliki persentase $62,49 \%$ sehingga sudah dapat dikatakan cukup baik, tetapi belum mencapai indikator keberhasilan. Hal ini disebabkan karena guru belum melakukan keseluruhan indikator proses kegiatan dalam pembelajaran. Pada siklus II persentase guru dalam kegiatan pembelajaran memiliki persentase $83,33 \%$ sudah dapat dikatakan baik.

3. Data Hasil Observasi Motivasi Belajar Siswa dalam Pembelajaran 
Data hasil observasi ini didapat melalui lembar observasi motivasi belajar siswa, dan digunakan untuk melihat proses dan perkembangan motivasi belajar yang terjadi selama pembelajaran berlangsung. Hasil analisis observer peneliti terhadap motivasi belajar siswa dalam pembelajaran masih terbilang kurang baik. Untuk lebih jelasnya dapat dilihat pada tabel berikut.

Tabel 3. Persentase Motivasi Belajar Siswa Siklus I dan Siklus II

\begin{tabular}{lcc}
\hline \multicolumn{1}{c}{ Indikator } & \multicolumn{2}{c}{ Persentase } \\
\cline { 2 - 3 } & Siklus I & Siklus II \\
\hline Motivasi siswa mengajukan pertanyaan & $34,58 \%$ & $76,92 \%$ \\
Motivasi siswa menjawab pertanyaan & $53,84 \%$ & $80,76 \%$ \\
\hline
\end{tabular}

Berdasarkan Tabel tersebut, dapat dikemukakan persentase motivasi belajar siswa pada bagian yang diamati yaitu (1) persentase motivasi siswa dalam mengajukan pertanyaan pada siklus I adalah $34,58 \%$. Berarti beberapa orang siswa sudah mulai berani mengajukan pertanyaan, hal itu disebabkan oleh adanya keberanian siswa yang dimunculkan guru menggunakan kartu bertanya. Pada siklus II persentase siswa dalam mengajukan pertanyaan meningkat menjadi $76,92 \%$, (2) persentase motivasi siswa dalam menjawab pertanyaan pada siklus I adalah 53,84\%. Berarti beberapa orang siswa sudah menjawab pertanyaan dalam kegiatan tanya jawab di kelas. Pada siklus II persentase siswa dalam menjawab pertanyaan meningkat menjadi $80,76 \%$.

4. Hasil Angket Motivasi Belajar Siswa

Angket digunakan untuk mengukur motivasi pembelajaran PKn siswa. Angket tersebut diberikan kepada setiap siswa. Guru mengolah angket tersebut menjadi sebuah nilai, untuk lebih jelasnya rekapitulasi hasil angket motivasi dapat dilihat pada tabel berikut.

Tabel 4: Hasil Angket Motivasi Belajar Siswa Siklus I dan Siklus II

\begin{tabular}{llcc}
\hline \multirow{2}{*}{ No } & \multirow{2}{*}{ Indikator } & \multicolumn{2}{c}{$\begin{array}{c}\text { Persentase yang diperoleh dari } \\
\text { Hasil Analisi Angket }\end{array}$} \\
\cline { 3 - 4 } & & Suklus I & Siklus II \\
\hline 1 & Keinginan siswa dalam memperoleh pengetahuan & $75,25 \%$ & $85,20 \%$ \\
2 & Kegiatan siswa dalam belajar & $68,42 \%$ & $82,33 \%$ \\
3 & Sesuai dengan keinginan & $65,06 \%$ & $75,08 \%$ \\
4 & Ganjaran sesuai dengan hasil belajar & $60,35 \%$ & 76,15 \\
\hline
\end{tabular}

Berdasarkan data yang terdapat pada tabel di atas, bahwa rekapitulasi hasil angket motivasi pada siklus I dan siklus II yaitu: (1) persentase rata-rata siswa yang memiliki keinginan untuk memperoleh pengetahuan adalah 75,25\% (motivasi siswa tinggi). Pada siklus II meningkat menjadi 85,20\% (motivasi siswa sangat tinggi), (2) persentase rata-rata siswa yang memiliki aktivitas dalam belajar adalah $68,42 \%$ (motivasi siswa tinggi). Pada siklus II meningkat menjadi 82,33\% (motivasi siswa sangat tinggi), (3) persentase rata-rata siswa sesuai dengan keinginan adalah $65,06 \%$ (motivasi siswa tinggi). Pada siklus II meningkat menjadi 75,08\% (motivasi siswa tinggi), (4) persentase rata-rata siswa yang ganjaran sebagai hasil belajar adalah 60,35\% (motivasi siswa cukup). Pada siklus II meningkat menjadi 76,15 (motivasi siswa tinggi).

Meningkatnya motivasi belajar siswa dari siklus I ke siklus II dikarenakan pada pembelajaran PKn menggunakan model everyone is a teacher here, model ini merupakan pembelajaran aktif yang memberikan peluang tumbuhnya kreativitas siswa sesuai dengan kemampuannya. Guru dalam proses pelaksanaan pembelajaran PKn sudah melaksanakan seluruh indikator dalam melaksanakan keterampilan mengajukan pertanyaan dan menjawab pertanyaan siswa lainnya. Maka dapat dikatakan bahwa penerapan model everyone is a teacher here pada pembelajaran PKn di kelas V SDN 138/III Tanjung Syam Kerinci berhasil meningkatkan motivasi dan hasil belajar siswa. Pembelajaran melalui model everyone is a 
teacher here dapat membuat siswa merasa senang dalam belajar terutama siswa yang aktif dalam proses pembelajaran. Dengan model everyone a is teacher here akan membuat siswa berani untuk menyampaikan sesuatu di depan teman-temannya. Siswa yang kurang aktif dapat menjadi aktif dikarenakan guru menggunakan secarik kertas/kartu indeks dalam pelaksanaan pembelajaran tersebut. Bagi siswa yang aktif akan menambah motivasi belajar dan siswa yang kurang aktif akan menjadi termotivasi untuk aktif dalam proses pembelajaran sehingga proses pembelajaran dapat berjalan dengan baik dan efektif.

\section{Kesimpulan}

Berdasarkan analisis hasil penelitian yang diperoleh, maka dapat diambil kesimpulan bahwa dengan menerapkan model everyone is a teacher here pada pembelajaran PKn di kelas V SDN 138/III Tanjung Syam Kerinci dapat meningkatkan motivasi belajar siswa. Hal ini terbukti dari penelitian yang penulis lakukan ada peningkatan motivasi dan hasil belajar siswa dari siklus I ke siklus II.

\section{Daftar Pustaka}

Andriani, A. (2020). Kajian The Body Of Knowledge Pendidikan Kewarganegaraan Dalam Konteks Pembelajaran Di Sekolah Dasar Sebagai Pendidikan Karakter. Dwija Inspira: Jurnal Pendidikan Multi Perspektif, 3(1), 13-26.

Astuti, A. (2016). Pengembangan Nilai-Nilai Kewarganegaraan Dalam Kegiatan Ekstrakurikuler Pramuka Di Sma Negeri 1 Kahu Kabupaten Bone. Jurnal Tomalebbi, 1(3), 19-26.

Farikhah, S. (2009). Keselarasan Pendidikan dengan Tingkat Perkembangan Anak. MUDARRISA: Jurnal Kajian Pendidikan Islam, 1(1).

Hamalik, Oemar. (2011). Proses Belajar Mengajar. Jakarta: Bumi Aksara.

Hamdi. (2011). Teori Kepribadian. Bandung: Upi SPs Press

Kompri. (2016). Motivasi Pembelajaran Perspektif Guru dan Siswa. Bandung: PT Rosda Karya.

Musdalifah, M. (2019). Peserta Didik Dalam Pandangan Nativisme, Empirisme, Dan Konvergensi. Idaarab: Jurnal Manajemen Pendidikan, 2(2), 243-251.

Rostini, T. (2018). Meningkatkan Pemahaman Siswa tentang Konsep Globalisasi dan Sikap Cinta Tanah Air melalui Metode Diskusi pada Mata Pelajaran PKn Kelas VI di SDN Nagrak 02 Kecamatan Sukaraja Kabupaten Bogor. MODELING: Jurnal Program Studi PGMI, 5(2), 171-184.

Samio, S. (2018). Aspek-Aspek Pertumbuhan Dan Perkembangan Peserta Didik. Best Journal (Biology Education, Sains and Technology), 1(2), 36-43.

Sanjaya, W. (2013). Penelitian Tindakan Kelas. Jakarta: Kencana

Shoimatul, U. (2013). Revolusi Belajar. Yogyakarta: Ar-ruzz Media

Simarmata, A. A. (2013). Hubungan Antara Motivasi Belajar dan Kecemasan pada Siswa Kelas Vi Sekolah Dasar. Jurnal Psikologi Udayana Vol. 1, No. 1.

Silberman, M. (2016). Active Learning 101 Cara Belajar Siswa Aktif. Bandung: Penerbit Nuansa

Suharsimi Arikunto, dkk. (2015). Penelitian Tindakan Kelas. Jarakarta: Bumi ksara.

Sudana, I. P. A., \& Wesnawa, I. G. A. (2017). Penerapan Model Pembelajaran Kooperatif Tipe STAD Untuk Meningkatkan Hasil Belajar IPA. Jurnal Imiah Sekolah Dasar, 1(1), 1-8.

Supriadi, A., \& Matnuh, M. H. (2014). Internalisasi Nilai Nasionalisme dalam Pembelajaran PKN Pada Siswa MAN 2 Model Banjarmasin. Jurnal Pendidikan Kewarganegaraan, 4(8), 120462.

Taufik, T. \& Muhammadi. (2009). Mozaik Pembelajaran Inovatif. Padang: Sukabina Press.

Yusrizal. (2010). Bahan Ajar PKn Kelas Tinggi. Padang: Kerja Sama Dikti Depdiknas dan Prodi PGSD FKIP Universitas Bung Hatta 